\title{
KLIMATIKUS ANOMÁLIÁK HATÁSA GYÜMÖLCSÖSÖK TÁPANYAG-GAZDÁLKODÁSÁRA
}

\author{
Nagy Péter Tamás - Szegedi László
}

\begin{abstract}
Absztrakt: Az időjárás szerepe a termés mennyiségére és minőségére ősidőktől fogva ismert. Napjainkban a gazdálkodóknak meg kell tanulniuk ezekkel az extrém időjárási események együtt élni és ellenük a lehető legjobb technológia alkalmazásával védekezni. Jelen munkámban azt mutatom be, hogy az időjárási hatások az utóbbi évtizedekben felerösödtek, hatásaik a mai - a termés mennyiségre és minőségre érzékeny - korban felértékelődtek. A dolgozatban több éves adatsorok elemzésével azt mutatom be, hogy az extrém időjárási események gyakran ciklikusan visszatérnek és az extrémitásuk fokozódásával hatásaik többéves vegetációs ciklusokra kihatnak jelentősen befolyásolva ezzel a termőhelyen kialakult termés nagyságát és minőségét.

Abstract: The role of weather of the quantity and quality has been knowing for ages. Todays, the farmers have to learn live together with these extreme weather events and do against them using the best technology. In this paper, I show that the effects of weather were became stronger in the last decades and their effects have been revaluated todays when we are sensible for the yield quantity and quality. In recent paper I'm showing that the extreme weather events often come back cyclical and by the increasing extremity of them, their effects extend for many years significantly affected the quantity and the quality of yield.
\end{abstract}

Kulcsszavak: klímaváltozás, tápanyag-gazdálkodás, gyümölcs

Keywords: climate change, plant nutrition, fruit

\section{Bevezetés}

A klimatikus hatások évezredeken át hatással voltak a mezőgazdasági termelésre. Az ember megpróbált mindenkor alkalmazkodni az időjárás gyakran gyorsan változó és hektikus hatásaihoz.

Régi tapasztalat, hogy a termés nagyságát és minőségét a talajtényezőkön, a tápanyag-ellátottságon, a növény genetikai tulajdonságain és az agrotechnikai beavatkozásokon túl az időjárási tényezők is alapvetően befolyásolják (1. ábra).

Nagyon nehéz feladat megbecsülni azt a terméskiesést és minőségromlás, ami optimális tápanyag-ellátottsági viszonyok biztosítása esetén, az időjárás, illetőleg az időjárási anomáliák számlájára írható. Az utóbbi évek extrém időjárási viszonyai (május eleji fagyok, nyár közepi aszály, őszi téli csapadékbőség, enyhe tél stb.) rámutattak, hogy a terméskiesés mértéke - termöhelytöl függöen - akár 100\%-os is lehet. Az elmúlt mintegy ötven év gyümölcsminöséggel foglalkozó szakirodalmi megállapításainak végső rezüméje az volt, hogy a termőhely megválasztásával a különböző éghajlati extrémitások döntően kiküszöbölhetőek (Trought et al., 1999). Ma már, ez az állítás kevésbé állja meg a helyét. Az éghajlati extrémitások olyan termöhelyeken is megjelennek, ahol korábban nem vagy csak kevésbé voltak jellemzőek.

Az éghajlat változása, a váratlan időjárási események gyakoriságának, valamint az anomáliák mértékének növekedése az egész világon egyre több problémát okoz a növénytermesztőknek. Hazánkban a szélsőséges időjárású évek különbözö gyakorisággal, rendszertelenül és nagyon nehezen becsülhetően fordultak elö az 
elmúlt ötven évben. A jövőre nézve nehéz jóslásokba bocsátkozni, viszont tény, hogy a fagyos és aszályos évek elöfordulási gyakorisága az utóbbi évtizedekben növekedett (Lakatos et al., 2005).

Ezzel a helyzettel a jövő gazdálkodóinak együtt kell élnie és a már bevált gyümölcstermesztési technológiákat finomítani, korrigálni kell ezekhez, az eseményekhez, mint befolyásoló tényezőkhöz - különben versenyképességük jelentősen csökken (Nagy et al., 2009a).

\section{1. ábra: A termés nagyságát és minőségét befolyásoló tényezők}

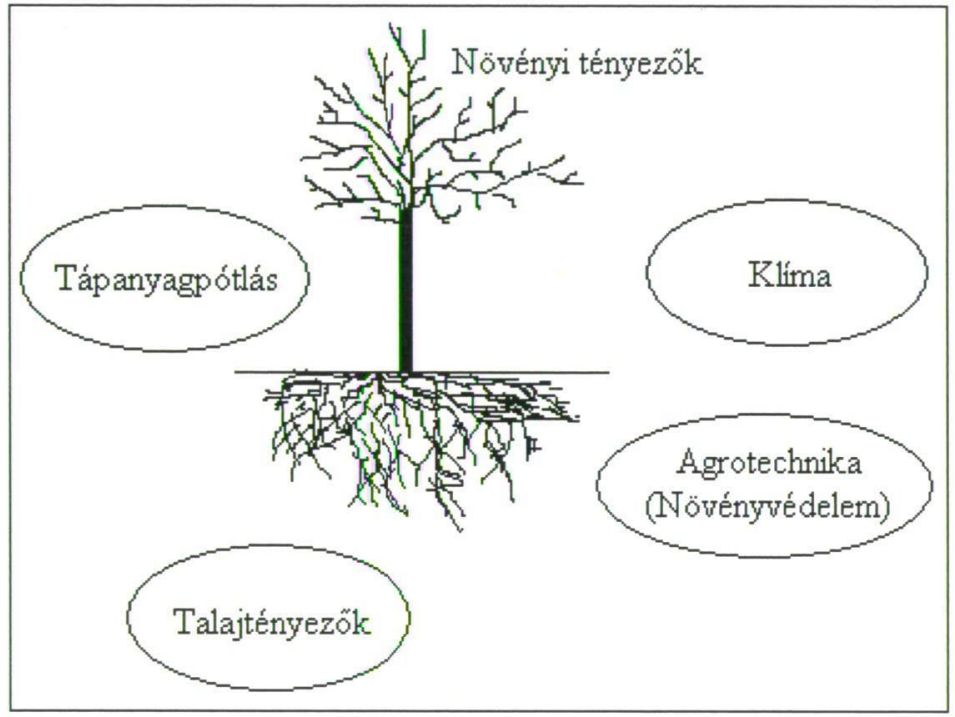

Forrás: saját szerkesztés

Különböző elemzések (szcenárióanalízis) és gyakorlati tapasztalatok alapján valószínüsíthető, hogy a hazai gyümölcstermelésre döntő befolyással nem a hőmérséklet növekedése, hanem az extrém időjárási jelenségek gyakorisága és kiszámítatlansága lesz (Soltész et al., 2006; Soltész et al., 2008; Nagy et al., 2009a,b,c).

Az időjárási tényezők alapvetően befolyásolják mind a talaj tápanyagszolgáltatását mind a növény tápanyagfelvételét. Hatásuk a fák tápelem-tartalmára, terméshozására és minőségére, igen bonyolult és összetett, amit a váratlan időjárási események bekövetkezése tovább bonyolít. Ezek az extrémitások alapvetően érintik a gyümölcsösök tápanyagpótlását, tápanyag-gazdálkodási stratégiáját. Éppen ezért a gyümölcsösökben, a jövőben, az éghajlati anomáliákhoz igazodó tápanyagutánpótlási koncepciót kell kidolgozni a klímaváltozás káros hatásainak kivédésére. Annál is inkább mert a gyümölcsfák évelő növények, az őket ért hatások évek múlva is kimutathatók és hatással vannak nemcsak a terméshozásra, hanem a termés minőségére is (Rodrigo, 2000).

Az extrém időjárási események minél pontosabb előrejelzése, az okozott károk felmérése, a fák fagy- és szárazságtürésének szabadföldi és laboratóriumi tesztelése 
közös feladata a termesztőnek, kutatónak és döntéshozónak egyaránt (Soltész et al., 2006).

A szélsőséges időjárási helyzetek valószínüsége, gyakorisága és mértéke hazánkban valószínüsíthetően növekedni fog az elkövetkező években (Várallyay, 2005; Láng et al., 2007; Pálfai, 2007).

Antal (2003) szerint 2050-ig a következő időjárási változásokra számíthatunk:

- nyáron $0,8^{\circ} \mathrm{C}$, télen $1-2,5^{\circ} \mathrm{C}$ hömérséklet-emelkedés,

- $\quad 10 \%$-os napfénytartam-növekedés,

- 20-100 mm közötti csapadékcsökkenés,

- a vegetációs periódus 10 napos meghosszabbodása.

Ezek következtében az alábbi hatások valószínüsíthetők a hazai gyümölcstermesztésben (Soltész et al., 2006 alapján):

- aszályok gyakoriságának, intenzitásának növekedése,

- a fokozódó transzspirációval nő a fák vízigénye,

- a csökkenő csapadék miatt romlik a fák vízigényének kielégítési kondíciói,

- nő az öntözés iránti igény, romolhat az öntözővíz minősége,

- csökken a termésbiztonság,

- gyümölcstermesztési zónák határvonalának eltolódása.

Ezek a hatások alapvetően érintik a gyümölcsösök tápanyagpótlását, tápanyaggazdálkodási stratégiáját. Éppen ezért az éghajlati anomáliákhoz igazodó tápanyagutánpótlási koncepciót kell kidolgozni a klímaváltozás káros hatásainak kivédésére.

Az időjárási tényezők (napfénytartam, hőmérséklet, csapadék, szél) alapvetően befolyásolják mind a talaj tápanyag-szolgáltatását mind a növény tápanyagfelvételét. Hatásuk a fák tápelem-tartalmára, terméshozására és minőségére, igen bonyolult és összetett, amit a váratlan időjárási események bekövetkezése tovább bonyolít.

\section{Anyag és módszer}

\subsection{Az időjárási esemény leírása}

2007. május elsején késő estétől másodikára virradó hajnalig és másodika késő estétől harmadikára virradó hajnalig az újfehértói Kutató Állomás (a vizsgált ültetvénytől mintegy $20 \mathrm{~km}$ távolságban) teleépített meteorológiai állomásán több órán keresztül $0,0^{\circ} \mathrm{C}$ alatti léghőmérsékleti értékeket regisztráltak a talaj közelben elhelyezett szondák (2. és 3. ábra). A fagyhatás több órán keresztül érzékelhetô volt, aminek köszönhetően az ültetvény magasabban fekvő részein szabad szemmel is látható fagyási tünetek jelentkeztek (4. ábra). 
2. ábra: Talaj-közeli hőmérsékletértékek (Újfehértó, 2007.05.01.-02. éjszakája)

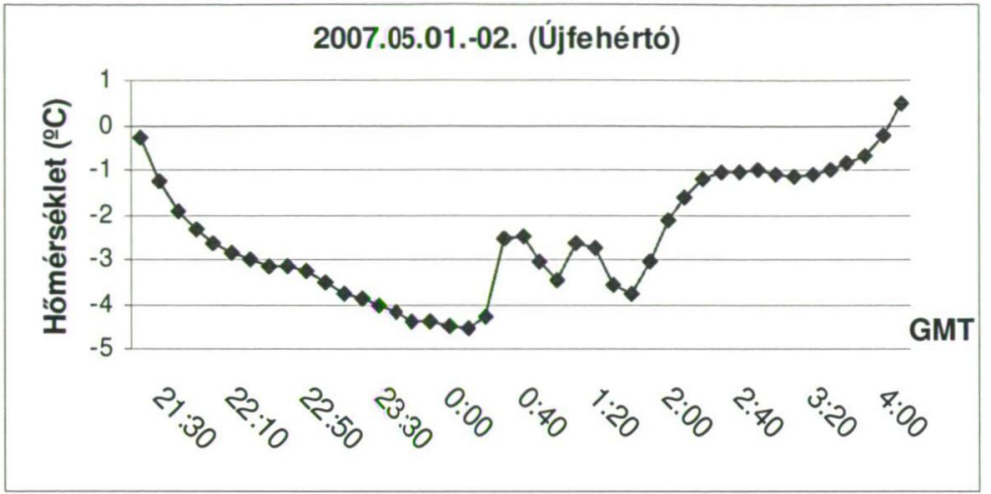

Forrás: (Nagy et al., 2009d)

\section{3.ábra: Talaj-közeli hőmérsékletértékek (Újfehértó, 2007.05.02.-03. éjszakája)}

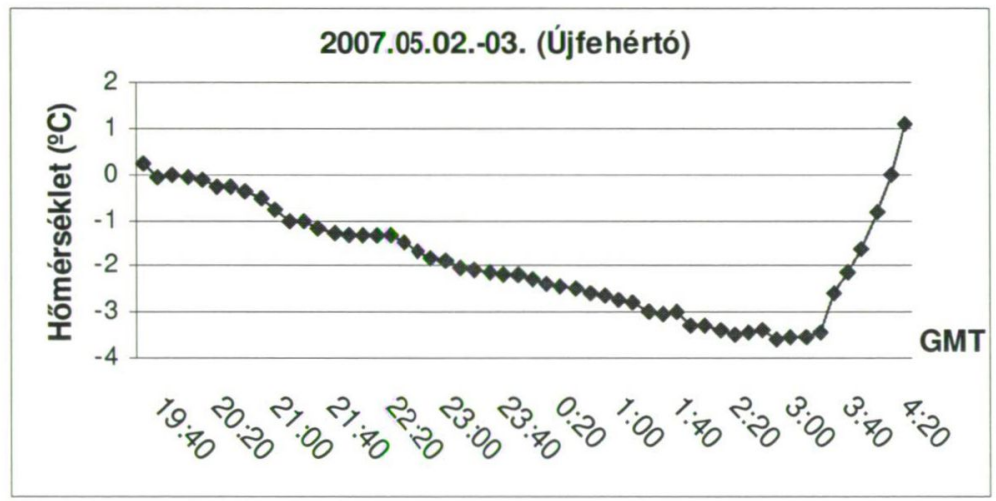

Forrás: (Nagy et al., 2009d)

\subsection{Vizsgálati helyszín}

Vizsgálatainkat a TEDEJ Rt. ültetvényében végeztük 2006 tavaszától kezdődően 2010 végéig. Az ültetvény talaja réti csernozjom típusú. Az ültetvényt 1999 őszén létesítették MM106-os alanyon 3,8 m x 1,1m sor- ill. tőtávolság mellett. A sorokban tíz fából álló blokkokat alakítottak ki. Az ültetvénykezelést az integrált normák szerint végezték. A tápelem-ellátottság megállapítására talaj és növényanalitikai vizsgálatokat végeztünk. Jelen tanulmányban csak a növénydiagnosztikai vizsgálatok szerepelnek.

A fagyhatást követően a tápanyagpótlási gyakorlaton nem változtattunk. A kialakult rendszertelen terméshozást sem korrigáltuk a vizsgálati területen, sem kézi, sem vegyszeres termésszabályozással. 


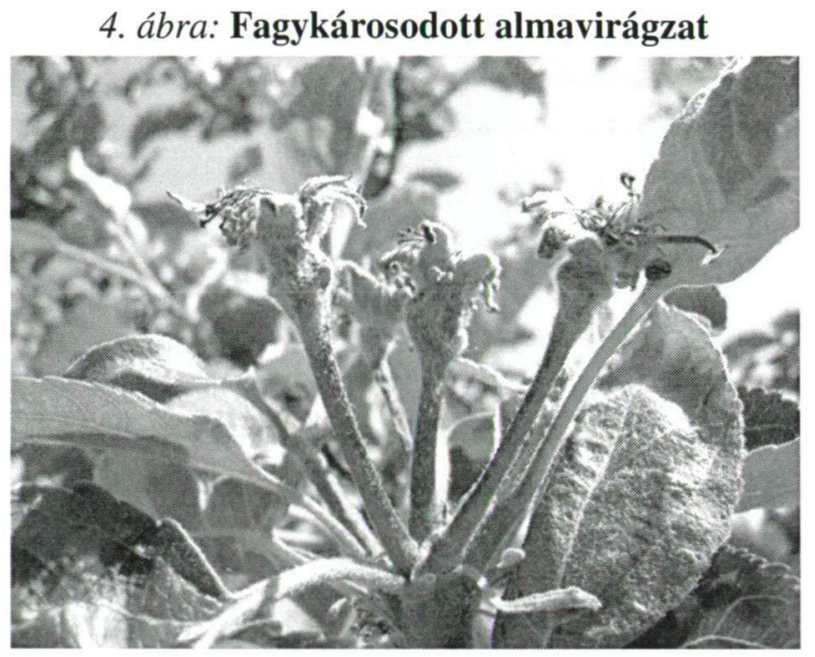

Forrás: (Nagy et al., 2009e)

\subsection{Vizsgálati módszer}

A levélminták vétele a szabványban leírt standard mintavételi időpontban történt. Levélvizsgálatra jól megvilágított, kifejlett, egészséges, a hosszú vegetatív hajtások végétől számított 4.-6. leveleket (levélnyéllel együtt) szedtük le, vállmagasságban, a négy égtájnak megfelelően elhelyezkedő egy-egy hajtásról, azonos ágemeletről.

A növénymintákat $70^{\circ} \mathrm{C}$-on szárítottuk, a nitrogén veszteség elkerülése végett majd daráltuk és a vizsgálatig papírzacskóban száraz, hűvös helyen tároltuk.

A növényminták N-tartalmát szárazégetéses módszerrel (Nagy, 2000), P-tartalmát fotometriás (foszfo-molibdenát módszer, Metertech VIS SP-850 Plus; Metertech Inc., Taipei, Taiwan), K-tartalmát emissziós lángfotometriás módszerrel határoztuk meg (Unicam SP90B Series 2 Atomic Absorption/Emission Spectrophotometer, PYE Unicam, England).

\section{Eredmények és értékelésük}

\subsection{Talajvizsgálati eredmények}

A helyszíni megfigyelések, valamint az általunk és a korábban elvégzett laboratóriumi vizsgálatok eredményei alapján a vizsgált terület talajtípusa csernozjom talaj, melynek altípusa réti csernozjom. A talaj káros sókat, gyökérfejlődést gátló talajhibát nem tartalmaz. Fizikai talajfélesége a vizsgált mélységben vályog, helyenként agyagos-vályog rétegekkel. Arany-féle kötöttségi száma átlagosan 45-nek adódott. Ezeknek megfelelően vízgazdálkodása, vízmegtartó képessége igen jó, jelentős szántóföldi vízkapacitással rendelkezik. A talajvíz 180-200 cm-en található. A talaj a vizsgált mélységig $(0-60 \mathrm{~cm})$ semleges közeli kémhatású $\left(\mathrm{pH}_{\mathrm{KCl}}=7,44\right)$.

A vizsgált talaj jelentős humusztartalommal rendelkezik $(\mathrm{Hu} \%=2,79)$, a humuszréteg vastagsága átlagosan $70-80 \mathrm{~cm}$. A humusztartalom a mélységgel 
csökkenö tendenciát mutat. A mért adatok alapján a vizsgált talaj $\mathrm{N}$-ellátottsága megfelelő. A könnyen oldható $\mathrm{N}$-formák közül döntően a magasabb oxidációs állapotú nitrát-forma jelenléte jellemzi a vizsgált talajréteget.

Megállapítható, hogy mind a nitrát- $\mathrm{N}-$, mind az ammónium- $\mathrm{N}$ tartalom a mélységgel csökken.

Az AL-oldható foszfor adatok alapján a talaj foszfor ellátottsága gyenge, értéke a mélységgel csökken. A talaj kálium ellátottsága az AL-oldható $\mathrm{K}$ értékek alapján gyengének mondható, értéke a mélységgel jelentősen csökken.

A terület talaja helyenként jelentős karbonát-tartalommal rendelkezik, ami mind a makro- mind a mikroelemek felvételét akadályozhatja. A vizsgált mikroelemek mennyisége a talajtípusnak megfelelő. Felvehetőséguiket elsősorban a talaj $\mathrm{pH}$, kötöttség, humusztartalom valamint a mésztartalom befolyásolja.

\subsection{Növényanalitikai következtetések}

Jelen tanulmányban négy almafajtánál kapott vizsgálati eredmények kerülnek bemutatásra (1. táblázat). A levelek nitrogén-, foszfor- és káliumtartalmát a bemutatott fajták esetén a 2006-2010-es időszakban az 1. táblázat mutatja. A vizsgált fajták leveleinek N-tartalma kedvező ellátottságot mutatott 2006-ban majd a fagyhatást követően elmaradt az optimálistól. A csökkenés hatására a fajták Nellátottsága a kedvezőből az alacsony kategóriába került. A fagykárt követő év adatai szignifikánsan alatta maradtak az azt megelőző majd az azt követő évek adataihoz képest. A csökkenés mértéke fajtánként különbözött, átlagosan mintegy $19 \%$ volt. Végül 2008-tól kezdődően ismét kedvezővé vált a levelek N-tartalma köszönhetően a tervezett tápanyagpótlásnak.

A fagykárt követő második évben a levél $\mathrm{N}$-tartalma minden fajta esetében nőtt és többnyire túlszárnyalta a fagykár előtti értéket. Ezt követően ismét kismértékü csökkenés majd ismét növekedés következett be a levelek $\mathrm{N}$-tartalmában. A kilengések (csökkenés-növekedés mértékének) amplitúdója azonban csökkent, egyre nivelláltabb, kiegyensúlyozottabb lett a levelek N-tartalma.

\section{1. táblázat: A vizsgált almafajták levelének $\mathbf{N}$-tartalma (Tedej, 2006-2010)}

\begin{tabular}{|c|c|c|c|c|c|}
\hline & 2006 & 2007 & 2008 & 2009 & 2010 \\
\hline Fajták & N (\%) (sz.a.) & $\mathbf{N}(\%)$ (sz.a.) & $\mathbf{N}(\%)$ (sz.a.) & $\begin{array}{l}\text { N (\%) } \\
\text { (sz.a.) }\end{array}$ & $\begin{array}{l}\text { N (\%) } \\
\text { (sz.a.) }\end{array}$ \\
\hline Idared & 2,10 & 1,73 & 2,11 & 2,04 & 2,14 \\
\hline Topáz & 2,44 & 1,73 & 2,19 & 2,11 & 2,17 \\
\hline Gála Must & 2,14 & 1,97 & 2,34 & 2,14 & 2,20 \\
\hline Summerred & 2,19 & 1,70 & 2,36 & 2,10 & 2,22 \\
\hline Átlag & 2,22 & 1,78 & 2,25 & 2,10 & 2,18 \\
\hline $\begin{array}{l}\text { SzD } D_{5 \%} \text { (éven belül) } \\
\text { SzD } D_{5 \%} \text { (évek között) }\end{array}$ & $\begin{array}{l}0,11 \\
0,08\end{array}$ & 0,08 & 0,07 & 0,06 & 0,07 \\
\hline
\end{tabular}

Az éven belüli szignifikáns differencia értéke többnyire kisebb volt, mint az évek közötti érték. Ez arra utal, hogy a fajtahatáson túl az éveknek jelentős hatása volt. 
A nitrogénnel ellentétes kezdeti lefutású hatást regisztráltunk a levelek foszforés a kálium-tartalmát illetően (2.-3. táblázat). A vizsgált fajták leveleinek P-tartalma kedvezö volt 2006-ban. A fagykárt követő mintavételnél jelentős növekedés mértünk a levél P-tartalmában. A növekedés mértéke 19 és $111 \%$ között jelentösen szórt. Valószínüsíthetően az egyes fajták eltérỏ érintettsége miatt. A következő években a levelek P-tartalma jelentősen csökkent majd stagnált és nem érte el a 2006-os év értékeit.

A foszfor-ellátottság 2008-tól kezdődően az alacsony, illetve a kedvezö ellátottsági kategória alsó szakaszában volt.

2. táblázat: A vizsgált almafajták levelének P-tartalma (Tedej, 2006-2010)

\begin{tabular}{|c|c|c|c|c|c|}
\hline & 2006 & 2007 & 2008 & 2009 & 2010 \\
\hline & & & & P (\%) & P (\%) \\
\hline Fajták & P (\%) (sz.a.) & $P(\%)$ (sz.a.) & P (\%) (sz.a.) & (sz.a.) & (sz.a.) \\
\hline Idared & 0,18 & 0,28 & 0,10 & 0,11 & 0,12 \\
\hline Topáz & 0,16 & 0,19 & 0,15 & 0,12 & 0,14 \\
\hline Gála Must & 0,18 & 0,23 & 0,15 & 0,14 & 0,12 \\
\hline Summerred & 0,18 & 0,38 & 0,13 & 0,17 & 0,13 \\
\hline Átlag & 0,18 & 0,27 & 0,13 & 0,14 & 0,10 \\
\hline$S_{z} D_{5 \%}(e ́ v e n$ beliil $)$ & 0,02 & 0,09 & 0,04 & 0,04 & 0,03 \\
\hline$S_{z z} D_{5 \%}(e ́ v e k k \ddot{z} z \ddot{t} t)$ & 0,06 & & & & \\
\hline
\end{tabular}

Hasonlóan a nitrogénnél tapasztaltakhoz a levelek tápelem-koncentrációiban mért kilengések (csökkenés-növekedés mértékének) amplitúdója csökkent, egyre nivelláltabb, kiegyensúlyozottabb lett a levelek P-tartalma, azonban a fagyhatás előtti kedvező tápelem ellátottságot a levelek P-tartalma még négy év eltelte után sem érte el.

A vizsgált almafajták levelének K-tartalmai a 3. táblázatban láthatók.

A vizsgált fajták leveleinek K-tartalma a Gála Must és Summerred fajtáknál kedvező, az Idarednél alacsony, a Topáznál hiányos volt 2006-ban. A 3. táblázat adataiból látható, hogy a vizsgált fajták leveleinek K-tartalma hasonlóan a foszfornál leírtakhoz, a fagyhatást követő évben nött, majd a következő évben csökkent. A fagykárt követő mintavételnél jelentős növekedés mértünk a levél $\mathrm{K}$-tartalmában minden fajta esetében. A növekedés mértéke 21 és $70 \%$ között jelentősen szórt.

Valószínűsíthetően az egyes fajták eltérő fagyérintettsége miatt. A következő években a levelek K-tartalma jelentősen csökkent majd stagnált és csak megközelítette a 2006-os év értékeit. 
3. táblázat: A vizsgált almafajták levelének K-tartalma (Tedej, 2006-2010)

\begin{tabular}{|c|c|c|c|c|c|}
\hline & 2006 & 2007 & 2008 & 2009 & 2010 \\
\hline Fajták & K (\%) (sz.a.) & K (\%) (sz.a.) & K (\%) (sz.a.) & $\begin{array}{l}\text { K (\%) } \\
\text { (sz.a.) }\end{array}$ & $\begin{array}{l}\text { K (\%) } \\
\text { (sz.a.) }\end{array}$ \\
\hline Idared & 1,11 & 1,40 & 1,04 & 1,11 & 1,10 \\
\hline Topáz & 0,74 & 1,26 & 1,04 & 1,01 & 0,98 \\
\hline Gála Must & 1,39 & 1,68 & 1,47 & 1,33 & 1,37 \\
\hline Summerred & 1,39 & 1,84 & 1,31 & 1,27 & 1,25 \\
\hline Átlag & 1,16 & 1,55 & 1,22 & 1,18 & 1,18 \\
\hline $\begin{array}{l}S_{z} D_{5 \%} \text { (éven beluil) } \\
S_{z} D_{5 \%} \text { (évek között) }\end{array}$ & $\begin{array}{l}0,21 \\
0,13\end{array}$ & 0,22 & 0,17 & 0,14 & 0,11 \\
\hline
\end{tabular}

A kálium-ellátottság 2008-tól kezdődően az alacsony ellátottsági kategóriában volt. Az évek közötti szignifikáns differencia értéke többnyire kisebb volt, mint az éven belüli érték. Ez arra utal, hogy a jelentősebb fajtahatáson túl az éveknek jelentős szerepe volt a kapott értékek alakulásában.

Eredményeink megerősítették azt a korábbi felismerést, hogy a termésterhelés és a levél tápelem tartalma szoros kapcsolatban áll egymással (Szủcs-Kállay, 1999; Szücs, 2008).

A 2007-es év tavaszi, közel 100\%-os fagyhatása szakaszos terméshozást, alternanciát indukált a fáknál. A fagy hatására lehullottak a virágok, gyümölcskezdemények a termés megsemmisült. Ennek hatására eltolódott a fák vegetatív-generatív egyensúlya. A gyümölcskezdemények, gyümölcsök hiánya vegetatív túlsúlyt eredményezett a fáknál, ami a levélméret növekedésben és a tápelem-koncentrációk változásában is megnyilvánult.

A levél tápelem-tartalmának abszolút értéke azonban sok esetben nem tájékoztat megfelelően a virágzási termékenyülési és fagyérzékenységi viszonyokról. Cerling (1971) valamint Báló et al. (1972) szerint ugyanis a N/K arány megváltozása és virágzáskori mennyiségük jobban befolyásolja a fagytürést és a következö évi virágfejlödést, mint a tápelem-tartalmak abszolút értékei. Ebből kiindulva, fajtaátlag adataink alapján számítottuk a három fỏ tápelem bináris arányait (4. táblázat).

\section{4. táblázat: Makrotápelem-arányok a vizsgált almafajták leveleiben} (fajtaátlag-adatok, Tedej)

\begin{tabular}{l|l|l|l}
\hline & N/P & N/K & P/K \\
\hline $\mathbf{2 0 0 6}$ & $\mathbf{1 2 , 3 3}$ & $\mathbf{1 , 9 1}$ & $\mathbf{0 , 1 6}$ \\
\hline $\mathbf{2 0 0 7}$ & 6,59 & 1,15 & 0,17 \\
\hline $\mathbf{2 0 0 8}$ & 17,31 & 1,84 & 0,11 \\
\hline $\mathbf{2 0 0 9}$ & 15,00 & 1,78 & 0,12 \\
\hline $\mathbf{2 0 1 0}$ & 21,80 & 1,85 & 0,08 \\
\hline Optimális* & $\mathbf{1 4 , 3 8}$ & $\mathbf{1 , 7 7}$ & $\mathbf{0 , 1 2}$ \\
\hline
\end{tabular}


A 4. táblázat adataiból látható, hogy az ültetvényben kiegyensúlyozott, az optimálishoz közeli tápelem-ellátottsági viszonyok uralkodtak a fagyhatást megelözően. A fagykárosodás évében a tápelem-arányok felborultak a fagy indukálta terméselmaradás miatt.

A N/P arány a fagyhatást követő évben sem állt helyre, sőt egyre jobban eltávolodott az optimálisnak tartott értéktől - köszönhetően a levélben mért alacsony foszfortartalmaknak. A N/K arány a fagyhatást követő években megközelítette az optimálisnak tartott értéket. A P/K arány a fagykárosodást megelőző évben kevésbé volt kedvezö. A fagyhatás eredményeképp a fagykár évében nőtt majd a következő években jelentösen csökkent, ami ugyan közelítette az optimális értéket, de a folyamatos tendenciájú csökkenés mégis kiegyensúlyozatlan tápelem-ellátásra utal.

\section{Következtetések, összegzés, záró megjegyzések, záró gondolatok}

Vizsgálataink célja a 2007. május eleji, virágzáskori közel 100\%-os fagykárosodás, almafák tápanyagfelvételére gyakorolt hatásainak megállapítása volt egy keletmagyarországi integrált almaültetvényben. A fagyhatást megelöző évben az ültetvényben az optimálishoz közeli tápelem-ellátottsági viszonyok uralkodtak. Eredményeink rámutattak, hogy a 100\%-os fagyhatás eltolta a fák vegetatívgeneratív egyensúlyát, a terméskiesés tápelem-ellátottsági zavarokat okozott, melyek az évelö jelleg miatt nemcsak a kurrens vegetációs időszakban, hanem azt követő években is jelentkeztek. A fagyot követően a közel $100 \%$-os terméskiesés döntően befolyásolta a fa kondícióját és az ültetvény egész területén bőséges virágzást és terméshozást okozott a következő évben. A fák vegetatív-generatív egyensúlyának eltolódása a levéldiagnosztikai vizsgálatokkal jól nyomon követhető volt. A fagy csökkentette az adott évben a fák levelének $\mathrm{N}$-tartalmát, míg növelte a P- és K-tartalmát. A következő évben épp fordított hatást tapasztaltunk.

A hatásokat elöre megjósolni nem lehet, azonban a fajok, fajták megválasztásánál, a termőhelyek kijelölésénél, a termesztéstechnológia kialakításánál és abban a tápanyagpótlás tervezésénél az éghajlati változások, anomáliák hatását a jövőben mindenképpen figyelembe kell venni, a versenyképes termelés érdekében.

\section{Irodalomjegyzék}

Antal E. (2003): Az éghajlatváltozás és a növényállományok vízellátottságának kérdőjelei a XXI. század elején. ,AGRO-21" Füzetek, 32: 25-48.

Lakatos L., Sümeghy Z., Szabó, Z., Soltész, M., Nyéki, J. (2005): Extrém időjárási eredmények elöfordulása és gyakoriságának változása a vegetációs időszakban. ,AGRO-21" Füzetek, 45: 3652.

Láng I., Csete L., Jolánkai M. (szerk.) (2007): A globális klímaváltozás: hazai hatások és válaszok. A VAHAVA jelentés. Szaktudás Kiadó Ház, Budapest.

Nagy P. T. (2000): Égetéses elven müködő elemanalizátor alkalmazhatósága talaj- és növényvizsgálatokban. Agrokémia és Talajtan, 49: 521-534.

Nagy P. T., Szabó T., Kincses I., Szabó Z., Nyéki J. (2009d): Tavaszi fagykár hatása 'Oblacsinszka' meggyfák tápanyag-felvételi dinamikájára. KLÍMA 21 FÜZETEK, 53: 65-71.

Nagy P. T., Szabó Z., Nyéki J. (2009a): Frost-induced nutrient disorders in integrated apple orchard. Cereal Res. Commun., 37 (Suppl. 2): 293-296. 
Nagy P. T., Szabó Z., Nyéki J., Soltész M. (2009b): Az alföldi gyümölcstermesztés helyzete, tápanyag-gazdálkodási problémái az éghajlatváltozás tükrében. In: Belanka Csaba - Duray Balázs (szerk.): Helyünk a világban - alföldi válaszok a globalizáció folyamataira. MTA RKK, 83-87.

Nagy P. T., Szabó Z., Nyéki J., Soltész M. (2009e): Tavaszi fagyhatás indukálta rendszertelen terméshozás és tápanyag-felvételi anomália integrált almaültetvényben. KLÍMA 21 FÜZETEK, 58: 58-64.

Nagy, P. T., Sípos, M., Szabó, Z., Soltész, M., Nyéki, J. (2009c): The effect of climatic anomalies on the nutrient-supply of fruit plantations. (Minireview) Int. J. Hort. Sci., 15 (1-2): 111-116.

Pálfai I. (2007): Éghajlatváltozás és aszály. KLÍMA 21 Füzetek, 49: 59-65.

Rodrigo, E.: (2000): Spring frost in deciduous fruit trees - morphological damage and flower hardiness. Scientia Hort. 85: 155-173.

Soltész, M., Nyéki, J., Szabó, Z., Lakatos, L. (2008): Globális éghajlatváltozás - az alföldi gyümölcstermesztés lehetöségei. AGTEDU 2008 Konferencia kiadvány, 136-141.

Soltész, M., Nyéki, J., Szabó, Z., Lakatos, L., Racskó, J., Holb, I., Thurzó, S. (2006): Az éghajlat- és időjárás-változás alkalmazkodási stratégiája a gyümölcstermelésben. In: Csete L., Nyéki J. (szerk.) Klímaváltozás és a magyarországi kertgazdaság. „AGRO-21” Kutatási programiroda, Akaprint Kft., Budapest.

Trought, M.C.T., Howell, G. S., Cherry, N. (1999): Practical Considerations for Reducing Frost Damage in Vineyards. Report to New Zealand Winegrowers.

Várallyay Gy. (2005): Magyarország talajainak vízraktározó képessége. Agrokémia és Talajtan. 54: $5-24$. 